\title{
Abhandlung
}

Karen Radner*

\section{A Neo-Assyrian Slave Sale Contract of 725 BC from the Peshdar Plain and the Location of the Palace Herald's Province}

DOI 10.1515/za-2015-0015

Abstract: This paper presents a first edition of a new clay tablet in Neo-Assyrian language and cuneiform script. The fragmentary text was found in 2013 at the site of Qalat-i Dinka in the Peshdar Plain, Sulaymaniyah Province, Kurdish Autonomous Region of Iraq. It documents the sale of a slave woman in the year $725 \mathrm{BC}$, when the area was part of the Assyrian Empire and quite possible of the Province of the Palace Herald.

In 2013, a farmer accidentally found a fragmentary Neo-Assyrian slave sale contract, on a field adjoining the settlement mound of Qalat-i Dinka in the province of Sulaymaniyah in the Kurdish Autonomous Region of Iraq. The new tablet as well as Neo-Assyrian pottery finds from nearby Gird-i Bazar indicate that the Peshdar Plain was part of the provincial system of the Assyrian Empire, rather than a region under the control of a client ruler. The new data moreover raise intriguing questions about the plain's exact position in the provincial system, the organisation of whose eastern holdings is currently still poorly understood.

During a visit to the Raniya region on 16 February 2015, the local representatives of the Sulaymaniyah Directorate of Antiquities and Heritage informed me that in 2013, a farmer had discovered a fragmentary cuneiform tablet while preparing a field for the cultivation of chickpeas. Qalat-i Dinka $\left(36^{\circ} 8^{\prime} 12^{\prime \prime} \mathrm{N}, 45^{\circ} 7^{\prime} 57^{\prime \prime}\right)$ is situated on the upper stretches of the Lower Zab, close to the village of Nuraddin and the town of Qalat Dizah in the Raniya district of the province Sulaymaniyah in the Kurdish Autonomous Region of Iraq.

A quick autopsy of the tablet in Raniya revealed that it was a slave sale contract in Neo-Assyrian language and script and it was taken to the Sulaymaniyah Archaeological Museum for further study. After preliminary cleaning by the staff of the conservation department, all preserved signs were perfectly legible. I made the hand copy and the photographs accompanying the present edition on 19 February 2015. My thanks go to the staff of the Sulaymaniyah Directorate of Antiquities and Heritage, especially

*Corresponding author: Karen Radner, Historisches Seminar, LMU München; Email: k.radner@Imu.de its director Kamal Rasheed, Saber Ahmed Saber, Barzan Baiz Esmail and Esmail Muhamad Ali, to the staff of the Sulaymaniyah Archaeological Museum, notably its director Hashim Hama Abdullah and conservator Akam Omar Ahmed, and to Jessica Giraud of the Institut français du Proche-Orient at Erbil.

In view of the discovery of a Neo-Assyrian legal document at Sitak near Sulaymaniyah in 2010 (Saber/Hamza/ Altaweel 2014; edition: Radner forthcoming), this is the second archival text of the Neo-Assyrian period from the Sulaymaniyah province. This new cuneiform tablet was exposed to fire in antiquity and is therefore in rather good condition, although only half of it is preserved. Despite this, the fragment contains key information about the purchase of a slave woman, dated to the reign of Shalmaneser $\mathrm{V}$ of Assyria (r. 726-722 BC): the date, the names of the parties involved and the purchase price, as well as part of the list of witnesses. The clay tablet's preserved dimensions are $3.8 \mathrm{~cm} \times 3.5 \mathrm{~cm}$ (broken) $\times 2.0 \mathrm{~cm}$.

\section{Transliteration}

Obv. 1 șu-pur mha-za EN MUNUS

2 f $k a b$-la-a GÉME-šú

3 ú-piš-ma mARAD-i

4 LÚ $^{\star}$.ARAD ša ${ }^{\mathrm{PN}} 15-\mathrm{BÀD}$

5 [ina Š]À-bi 28 MA.NA URUDU.MEŠ

6 [il-qe G]ÉME $z a r_{4}$-pi-<at>

7 [la-qi-a]t kás-pi

Rest lost 
Rev. Beginning lost

$$
\begin{aligned}
& 1^{\prime} \text { IIGI mnil-[nu]-[ } a{ }^{1}-a \\
& 2^{\prime} \text { IGI mha-ru-a-ṣu } \\
& 3^{\prime} \quad \text { LÚ }{ }^{\star} \text {.ARAD ša LU }{ }^{\star} \text {.NIMGIR-KUR } \\
& \text { 4' ITU.GU }{ }_{4} \text { lim-mu } \\
& \text { 5' mmah-de-e }
\end{aligned}
$$

\section{Translation}

Fingernail impression(s) of Hazā, owner of the woman. Kablâ, his slave woman - Urdî, servant of Issār-dūrī, has contracted and [bought] her [f] or 28 minas of copper. The slave woman is purchased [and acquir]ed. The money [is paid completely.]

$[\ldots]$

Witness Ni[nu]āyu. Witness Haruașu, servant of the Palace Herald.

Month Ayyaru (ii.), eponym year of Mahdê.

\section{Commentary}

1-2: The vendor is Hazā, who sells the slave woman Kablâ. Both their names are West Semitic. Hazā derives from the root hizy "to see" (PNA 2/1, 467 s. v.). The female name Kablâ is attested for the first time in the Neo-Assyrian onomasticon but certainly a qatl formation of the root $\mathrm{kbl}$ "to bind" (compare the composite names Kablu-Aššur and Kablu-Issār: PNA 2/1, 592 s. v.). The vendor is said to have sealed the tablet with his fingernail impression. This is fairly common with Neo-Assyrian contracts of the $8^{\text {th }}$ century BC. The impressions were usually applied directly under the identification of the seller (Radner 1997, 36-39), but this is not the case here. The fingernail impressions are lost with the missing half of the tablet.

3-4: The purchaser is Urdî, subordinate to a man called Issār-dūrī. Both bear very common Assyrian names (PNA 3/2, 1393 s. v.; PNA 2/1, 568 s. v.).

5: The purchase price is 28 minas of copper, corresponding to about 14 kilos of copper. Copper is the most frequently attested currency in the Assyrian Empire before Carchemish was conquered in 717 $\mathrm{BC}$, leading to an enormous influx of silver into the Assyrian economy (Müller 1997, 120; Radner 1999, 129, 139f.). We can compare Kablâ's price with the few other copper prices for people avail- able for the second half of the $8^{\text {th }}$ century BC: 74 minas of copper for a group of three men and two women, that is, just under 15 minas per person, in $737 \mathrm{BC}(\mathrm{SAA} 6,2)$ and 180 minas of copper for a family of two men and five women, that is, just over 25 minas per person, in $713 \mathrm{BC}$ (SAA 6, 6). The price for Kablâ is therefore not out of the ordinary, especially when taking into account that buying groups of people, usually families, generally results in cheaper unit prices (Radner 1997, 248).

To how much silver would have 28 minas of copper corresponded at that time? In the Khorsabad Annals inscription, Sargon records for the year $712 \mathrm{BC}$ how his military triumphs against the Neo-Hittite states had made him master over various metal deposits, and fuelled Assyrian mining and metallurgy, resulting in the exchange value (mahiru) of silver equalling that of "bronze" (ZABAR, which in the context of the Assyrian royal inscriptions stands for both copper and bronze, see Zaccagnini 1971, Fales 1996, 17-19 and Radner 1999, 128 n. 7): "People paid the exchange rate for silver within the country of Assyria as if it were bronze/copper" (Fuchs 1994, $130 \mathrm{f}$. Ann. 232-234). This statement is generally interpreted in the context of the literary topos of the "fair price" to express the royal duty of causing prosperity and wellbeing for the subjects (e.g. Vargyas 1997, 185-190) and therefore cannot be taken to reflect economic reality. Over time, the exchange rate between copper and silver varied substantially, reflecting local market conditions (cf. Fales 1996, 20-26). But very roughly, we may assume a basic ratio of 1 mina = 60 shekels of copper to 1 shekel of silver. The best indication for this is a set of exchange rates for barley given in purchase documents of the year $698 \mathrm{BC}$ during a time of economic crisis when the equivalent of 2 seah of barley is given as one mina of copper in a contract from Assur and as one shekel of silver in a document from Huzirina (Radner 1999, 157: VAT 9359 and $S U$ 51/36).

6-7: $\quad$ This stands for the standard completion clause amtu zarpat laqe'at "The slave woman is purchased and acquired" but the realisation of the stative form of zarpat is peculiar. We can either assume that the scribe erroneously omitted the last sign, as I have done in my transliteration, or else see the spelling in the context of the very frequent mistakes attested in this specific clause when purchase contracts were recorded 

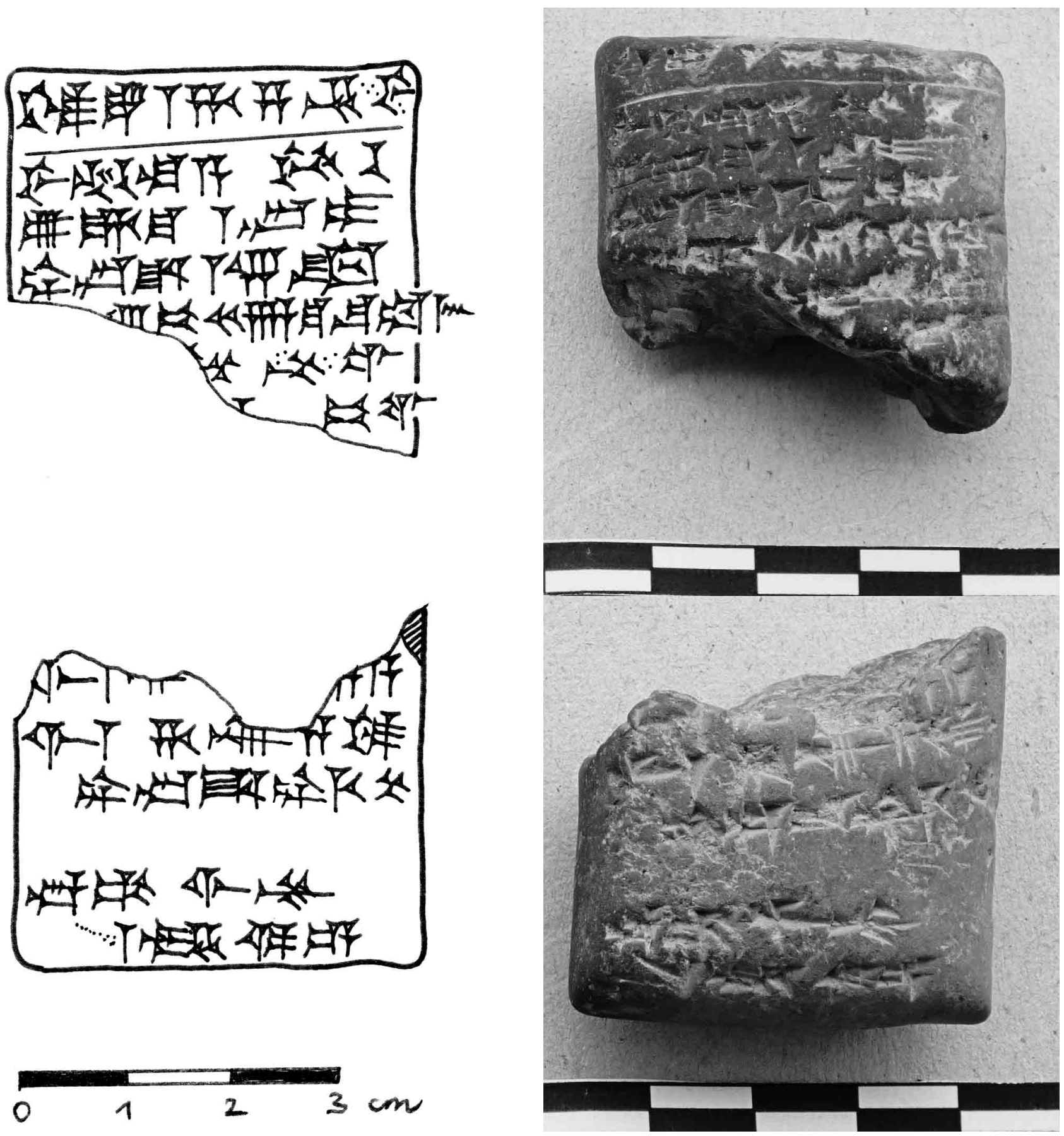
by writers whose native language did not sufficiently prepare them to understand the Assyrian stative verbal forms. This is very well documented for the Neo-Assyrian legal texts from DurKatlimmu in Syria where the scribes' native tongue was often Aramaic (Radner 2002, 20 f.). In light of the fact that vendor and slave in our text have West Semitic names, assuming a similar scenario for the Raniya Plain is certainly possible. But we can take for granted that in the $8^{\text {th }}$ century $\mathrm{BC}$, Hurrian and Indo-European languages were spoken locally in the Zagros region. Cf. also the non-Semitic name of the witness in Rev. $2^{\prime}$.

Rev. 1': The suggested restoration of the name of the penultimate witness is a good option, given the surviving traces, and Ninuāyu "Man from Nineveh" is moreover a very common Neo-Assyrian name (PNA 2/2, 964 s. v.).

Rev. 2': The name of the last witness, Haruașu, is another new addition to the known Neo-Assyrian onomasticon. It is perhaps related to the names Harrușu, Harṣu, Harșû and/or Haruṣâ, all of unknown origin and etymology (PNA 2/1, 462f. s. v.). In any case, the name Haruașu is not Semitic.

Rev. 3': The identification of Haruașu as a subordinate of the Palace Herald strongly suggests that the transaction took place in the province of the Palace Herald. The identity of the Palace Herald in $725 \mathrm{BC}$ is currently not known. There are several options:

a) Bēl-Harrān-bēlu-ușur, who was reinstated in this office by Tiglath-pileser III (r. 744-727 BC) in 744 $\mathrm{BC}$ and served as eponym in $741 \mathrm{BC}$. He had been first appointed Palace Herald by Shalmaneser IV (r. 782-773 BC) at some point after 778 (PNA 1/2, 30 s. v.; Mattila 2000, 31). If he still served as Palace Herald in 725 BC, he would have been very old. If he kept the office even after Sargon II came to the throne (cf. below on Rev. $5^{\prime}$ for Mahdê, governor of Nineveh, where this was indeed the case), his advanced age would help explain the unusually prominent and active role played by the Deputy Palace Herald Šulmu-Bēl who was a frequent correspondent of Sargon II (SAA 5, 133-144). Shown beardless on his stela from Tell Abta (Unger 1917; Grayson 1996, 241f. A.0.105.2), Bēl-Harrān-bēluușur was a eunuch.

b) Ahū'a-āmur, who is known as Palace Herald from the inscription of the seal of his major-domo Nabû-nūrka-lāmur, depicted as a eunuch in prayer on his seal (Watanabe 1993, 119, pl. 5 no. 7.7). Another seal, identifying its owner only as Ahū'a-āmur (Watanabe 1993, 119, pl. 5 no. 7.6), shows a eunuch in prayer before a god on a bull. Given its high quality, the seal would certainly have been fit for a Palace Herald. The chronological position of this Palace Herald, however, is uncertain although nothing excludes dating both seals to the second half of the $8^{\text {th }}$ century BC. Ahü'a-āmur, who is not attested as a year eponym, may have been Bēl-Harrān-bēlu-ușur's successor, appointed either late in the reign of Tiglath-pileser III or when Shalmaneser V came to the throne.

c) Gabbu-ana-Aššur is only a possibility if one accepts the hypothesis, formulated on the basis of his letters to the king (SAA 5, 113-121), that he was the Palace Herald under Sargon II (Mattila 2000, 32; PNA 1/2, 413 s. v.). He is not attested as a year eponym.

Rev. 4': No day is given in the date, which is rather unusual in private legal documents but attested once in a while. For the $9^{\text {th }}$ and $8^{\text {th }}$ centuries BC, note Edubba 10, 1 (844), Edubba 10, 2 (800), CTN 2, 51 (797 BC), Edubba 10, 5 and 7 (both 788 BC), CTN 2, 104 (748 BC), SAA 6, 25 (717 BC), CTN 2, 255 and StAT 3, 27(both $715 \mathrm{BC}$ ).

Rev. $5^{\prime}$ : The purchase of the slave woman took place in the second month of the eponym year of Mahdê, the governor of Nineveh under the kings Shalmaneser V (r. 726-722 BC) and Sargon II (r. 721-705 BC). He served as eponym under Shalmaneser in 725 BC (Millard 1994, 45) and later was a correspondent of Sargon (SAA 5, 74-76). This is the first attestation of this eponym in an archival text (PNA 1/1, 104 sub Ammī-ḩātî).

\section{The Province of the Palace Herald}

The location of the Palace Herald's province, one of the Assyrian border marches created for the Empire's defence in strategically vulnerable positions (Liverani 2004, 218), is certainly to the east of the Assyrian heartland but its precise whereabouts are currently unknown. On the basis of the available references in Neo-Assyrian inscriptions and archival materials (conveniently collected in Mattila 2000, 34-37), Postgate $(1995,9)$ thought the plain of Rowanduz "a distinct possibility" (followed by Radner 2006, 49) whereas Liverani $(2004,218)$ suggested a location 
"probably on the upper valley of the Lower Zab". With the Qalat-i Dinka tablet providing new evidence, Liverani's proposal seems now more likely; the Palace Herald's province may well have been centred in the Raniya region.

Qalat-i Dinka and the nearby Neo-Assyrian site of Gird-i Bazar ( $36^{\circ} 8^{\prime} 18^{\prime \prime} \mathrm{N}, 45^{\circ} 8^{\prime} 28^{\prime \prime}$ E; good Neo-Assyrian pottery collected during my visit on 18 February 2015 and during the Sulaymaniyah governorate survey of the Institut Français du Proche-Orient at Erbil, directed by Jessica Giraud) are situated only about $37 \mathrm{~km}$, as the crow flies, from the Mannean site of Rabat Tepe $\left(35^{\circ} 3^{\prime} 29^{\prime \prime} \mathrm{N}\right.$, $\left.46^{\circ} 54^{\prime} 56^{\prime \prime} \mathrm{E}\right)$ in the Iranian province of Western Azerbaijan (Kargar/Binandeh 2009). If one follows the course of the Lower Zab, one reaches a pass at an altitude of merely $923 \mathrm{~m}\left(36^{\circ} 1^{\prime} 52^{\prime \prime} \mathrm{N}, 45^{\circ} 21^{\prime} 8^{\prime \prime} \mathrm{E}\right)$ that conveniently leads across the Zagros into Mannean territory (and today the Republic of Iran). As the finds from Qalat-i Dinka and Gird-i Bazar demonstrate that the Peshdar Plain was Assyrian, it would make good sense to protect this exposed region by turning it into a heavily militarized border march.

In the late $8^{\text {th }}$ century $\mathrm{BC}$, the kingdom of Mannea, with which, as this new data demonstrates, the Assyrian Empire shared a direct border, was not only a powerful territorial state but also politically torn in its loyalties between its neighbours Assyria and Urartu (see Fuchs $1994,447-450$ on the situation during the late $8^{\text {th }}$ century $\mathrm{BC})$. Further exploration of the Assyrian border in the Peshdar Plain will certainly result in an improved understanding of the border marches under the command of the highest military officials of the Assyrian Empire, whose role in the provincial system must have differed considerably from that of standard provinces under the authority of a governor.

\section{Abbreviations}

CTN 2 = J. N. Postgate, The Governor's Palace Archive. Cuneiform Texts from Nimrud 2. London 1973

Edubba $10=$ A. Y. Ahmad/J. N. Postgate, Archives from the Domestic Wing of the North-West Palace at Kalhu/Nimrud. Edubba 10. London 2007

PNA $1 / 1=K$. Radner (ed.), The Prosopography of the Neo-Assyrian Empire, 1/1: A, Helsinki 1998

PNA $1 / 2=K$. Radner (ed.), The Prosopography of the Neo-Assyrian Empire, 1/2: B-G, Helsinki 1999

PNA 2/1 = H. D. Baker (ed.), The Prosopography of the Neo-Assyrian Empire, 2/1: $\mathrm{H}-\mathrm{K}$, Helsinki 2000

PNA 2/2 = H. D. Baker (ed.), The Prosopography of the Neo-Assyrian Empire, 2/2: L-N, Helsinki 2001

PNA $3 / 2=$ H. D. Baker (ed.), The Prosopography of the Neo-Assyrian Empire, 3/2: Š-Z, Helsinki 2011
SAA $5=$ G. B. Lanfranchi/S. Parpola, The Correspondence of Sargon II, Part II. Letters from the Northern and Northeastern Provinces. State Archives of Assyria 5. Helsinki 1990

SAA $6=$ T. Kwasman/S. Parpola, Legal Transactions of the Royal Court of Nineveh, Part I. Tiglath-Pileser III through Esarhaddon. State Archives of Assyria 6. Helsinki 1990

StAT $3=$ B. Faist, Alltagstexte aus neuassyrischen Archiven und Bibliotheken der Stadt Assur. Studien zu den Assur-Texten 3. Wiesbaden 2007

\section{Bibliography}

Fales, F. M. (1996): Prices in Neo-Assyrian sources, State Archives of Assyria Bulletin 10, 11-53

Fuchs, A. (1994): Die Inschriften Sargons II. aus Khorsabad, Göttingen

Grayson A. K. (1996): Assyrian Rulers of the Early First Millennium BC, II. 858-745 BC. The Royal Inscriptions of Mesopotamia. Assyrian Periods 3. Toronto

Kargar, B./A. Binandeh (2009): A preliminary report of excavations at Rabat Tepe, Northwestern Iran, Iranica Antiqua 44, 113-129

Liverani, M. (2004): Assyria in the ninth century: continuity or change? In: G. Frame (ed.), From the Upper Sea to the Lower Sea. Studies on the History of Assyria and Babylonia in Honour of A. K. Grayson, Istanbul/Leiden, 213-226

Mattila, R. (2000): The King's Magnates. A Study of the Highest Officials of the Neo-Assyrian Empire. State Archives of Assyria Studies 11. Helsinki

Millard, A. (1994): The Eponyms of the Assyrian Empire 910-612 BC. State Archives of Assyria Studies 2. Helsinki

Müller, G. (1997): Gedanken zur neuassyrischen 'Geldwirtschaft', in: H. Hauptmann/H. Waetzoldt (eds.), Assyrien im Wandel der Zeiten. Heidelberger Studien zum Alten Orient 6. Heidelberg, 115-121

Postgate, J. N. (1995): Assyria. The home provinces, in: M. Liverani (ed.), Neo-Assyrian Geography, Rome, 1-17 (reprinted in J. N. Postgate, The Land of Assur and the Yoke of Assur. Studies on Assyria 1971-2005. Oxford 2007, 243-259)

Radner, K. (1997): Die neuassyrischen Privatrechtsurkunden als Quelle für Mensch und Umwelt. State Archives of Assyria Studies 6. Helsinki

Radner, K. (1999): Money in the Neo-Assyrian Empire, in: J. G. Dercksen (ed.), Trade and Finance in Ancient Mesopotamia. Istanbul/Leiden, 127-157

Radner, K. (2002): Die neuassyrischen Texte aus Tall Šēh Ḥamad. Beiträge zu den Ausgrabungen von Tall Šèh Ḥamad 6. Berlin

Radner, K. (2006): Provinz. C. Assyrien, Reallexikon der Assyriologie und Vorderasiatischen Archäologie 11/1-2, 42-68

Radner, K. (forthcoming): A Neo-Assyrian legal document from Tell Sitak, in: Y. Heffron/A. Stone/M. Worthington (eds.), At the Dawn of History. Ancient Near Eastern Studies in Honour of J. N. Postgate, Winona Lake, IN

Saber, S. A./H. Hamza/M. Altaweel (2014): Report on the excavations at Tell Sitak. The 2010 season, Iraq 76, 205-229 
Unger, E. (1917): Die Stele des Bel-harran-beli-ussur. Ein Denkmal der Zeit Salmanassars IV. Publikationen der Kaiserlich Osmanischen Museen 3, Konstantinopel

Vargyas, P. (1997): Getreidekursangaben und Preistarife in Assyrien und Babylonien des 2. und 1. Jahrtausends, in: H. Hauptmann/H. Waetzoldt (eds.), Assyrien im Wandel der Zeiten. Heidelberger Studien zum Alten Orient 6. Heidelberg, 185-190

Watanabe, K. (1993): Neuassyrische Siegellegenden, Orient. Report of the Society for Near Eastern Studies in Japan 29, 109-138

Zaccagnini, C. (1971): La terminologia accadica del rame e del bronzo nel 1 millennio, Oriens Antiquus 10, 123-144 